\title{
Effects of Microstructures on the Mechanical Properties of Multi-phase Sheet Steels*
}

\author{
By Masatoshi SUDO,** Masanori HIGASHI,** Hiromi HORI,** \\ Takafusa IWAI,** Shoji KAMBE** and Zenichi SHIBATA**
}

\begin{abstract}
Synopsis
Several microalloyed steels were intercritically annealed and then aircooled to room temperature or water-quenched to obtain different microstructures. The effects of the amount and the nature of low-temperature transformation products on the deformation behavior, stretch-flangeability and fracture-toughness after cup deep-drawing of multi-phase sheet steels were examined. Bainite has a slight deleterious effect on strength-uniform elongation relationship but has a favorable effect on stretch-flangeability and on fracture toughness after cup deep-drawing as compared with martensite. It is also suggested that ferritic-bainitic (-martensitic) steel may be preferred to "dual phase" steel in some complex pressings.
\end{abstract}

\section{Introduction}

The development of sheet steel with a dual phase ferrite-martensite microstructure has received considerable attention from automotive and steel industries because of its good strength-formability relationships. ${ }^{1-3)}$ The steel is generally characterized by continuous yielding behavior, low yield-to-tensile strength ratio, and high uniform elongation. So far, the studies were limited to the comparison of the tensile properties of ferrite-martensite steels with those of conventional HSLA steels. With regard to microstructure, the effect of hardness or fractions of second phase on the stress-strain curve and on strength-ductility relationships has already been examined. ${ }^{3-6)}$ Little information was, however, published on the relationships between the type of hard phases (martensite, bainite) of multi-phase steel sheets, and press form- ability and fracture toughness of deep drawn cups.

Therefore, the present study was undertaken i) to clarify the effect of nature of low-temperature transformation products on elimination of yield point elongation and on decrease in yield ratio, and ii) to study the effect of bainite on the stretch-flanging formability and fracture toughness of deep-drawn cups in comparison with that of martensite.

\section{Experimental Procedure}

Vacuum melted alloys were hot forged and hot rolled to $3.2 \mathrm{~mm}$ thickness and air cooled to room temperature. The composition of these alloys are presented in Table 1 . They were reheated to $650^{\circ} \mathrm{G}$ for $2 \mathrm{hr}$, furnace cooled to precipitate $\mathrm{AlN}$, then cold rolled to $0.8 \mathrm{~mm}$ thickness. The cold rolled sheet samples were heat treated in order to obtain the different microstructures.

Blanks for all the tensile specimens were cut parallel to the rolling direction. Tensile specimens, $12.5 \mathrm{~mm}$ wide and with a gauge length of $50 \mathrm{~mm}$, were prepared, and tested at room temperature on an Instron machine with a cross head speed of $10 \mathrm{~mm} / \mathrm{min}$.

Microstructural examinations were made on a cross-section perpendicular to the rolling direction. The microstructure of each sample was delineated using LePera's method, ${ }^{7)}$ and examined by transmission electron microscopy. The volume fraction of martensite and bainite was determined by using the

Table 1. Chemical composition. (wt \%)

\begin{tabular}{|c|c|c|c|c|c|c|c|c|c|c|}
\hline Steel & C & $\mathrm{Si}$ & $\mathrm{Mn}$ & $\mathbf{P}$ & $\mathrm{S}$ & $\mathrm{Cr}$ & $\mathrm{Al}$ & $\mathrm{Nb}$ & Mo & B \\
\hline A & 0.06 & & 1.23 & 0.05 & & 0.48 & 0.02 & & & \\
\hline B & 0.06 & & 1.30 & 0.05 & & & 0.02 & & & \\
\hline G & 0.06 & & 2.25 & 0.05 & & 0.49 & 0.02 & & & \\
\hline D & 0.05 & & 1.24 & 0.04 & & 0.94 & 0.02 & & & \\
\hline $\mathrm{E}$ & 0.052 & 1.00 & 0.49 & 0.004 & 0.014 & & 0.018 & & & \\
\hline $\mathrm{F}$ & 0.053 & 1.98 & 0.99 & 0.005 & 0.017 & & 0.024 & & & \\
\hline G & 0.049 & 0.98 & 0.98 & 0.005 & 0.015 & & 0.016 & & & \\
\hline $\mathrm{H}$ & 0.060 & $<0.03$ & 0.99 & 0.005 & 0.004 & & 0.052 & & & \\
\hline I & 0.041 & 0.48 & 1.54 & & & 0.51 & 0.035 & & & \\
\hline $\mathrm{J}$ & 0.06 & 0.53 & 1.47 & 0.008 & 0.012 & 0.52 & 0.016 & 0.03 & & \\
\hline $\mathrm{K}$ & 0.06 & 0.52 & 1.51 & $<0.003$ & $<0.008$ & 1.01 & 0.004 & & 0.38 & \\
\hline $\mathrm{L}$ & 0.06 & 0.50 & 1.45 & & & 0.98 & 0.027 & & & 0.0014 \\
\hline $\mathrm{M}$ & 0.040 & 0.25 & 0.40 & 0.085 & 0.015 & & 0.050 & & & \\
\hline $\mathrm{N}$ & 0.040 & 0.25 & 0.40 & 0.085 & 0.015 & & 0.050 & 0.015 & & \\
\hline
\end{tabular}

* Based on the papers presented to the symposium of the 100th ISIJ Meeting, October 1980, at Kyushu University, Fukuoka, (published in Tetsu-to-Hagané, 66 (1980), A197, in Japanese) and presented to the Paper Presentations of the 101st ISIJ Meeting, April 1981, at The University of Tokyo, Tokyo. English manuscript received April 3, 1981.

** Central Research Laboratory, Kobe Steel, Ltd., Wakinohama-cho, Chuo-ku, Kobe 651. 
Quantimet image analysis.

Internal friction studies at the frequency of about $340 \mathrm{C} / \mathrm{s}$ were performed on some samples in order to determine solute carbon concentration in the ferrite in $(\alpha+\gamma)$ region. Electrical resistivity measurements were carried out to determine the transformation temperature in the cooling at the rate of $10^{\circ} \mathrm{G} / \mathrm{s}$.

The hole expanding test of punched hole was carried out to clarify the effect of hard phases on the stretch flangeability of multi-phase steels. The initial hole diameter was $5 \mathrm{~mm}$ and a conical punch with a top angle of $60^{\circ}$ was adopted.

The hole expanding limit $\lambda$ was expressed as the average stretch of the hole edge by the following equation;

$$
\lambda=\frac{d_{B}-d_{i}}{d_{i}}
$$

where, $d_{i}:$ initial hole diameter

$d_{B}:$ fractured hole diameter.

The fracture hole diameter was determined when the crack developed fully in the sheet thickness.

In determining the fracture toughness of a deep drawn cup, a short ring test specimen $\left(10 \mathrm{~mm}^{l}\right)$ was used. The ring was cut transversely from a cup at a deep drawing ratio of 2.0 , and a V-shaped $1 \mathrm{~mm}$ depth notch was made in the rolling direction. The short ring extension test was conducted at various low temperatures. The transition temperature and the unit crack path were determined by direct observation of the fracture surface with a scanning electron microscopy.

The steels $A \sim D$ were mainly used in this study. The other steels were only used for determining hole expanding limit and transition temperature.

\section{Results and Discussion}

\section{Yield Ratio and Yield Point Elongation}

Effects of annealing condition on the mechanical properties were, at first, examined using steels $\mathrm{A} \sim \mathrm{D}$. The cold rolled sheet samples were individually heated in salt bath, then air cooled to room temperature, or water quenched. The air cooling rate was approximately $10^{\circ} \mathrm{C} / \mathrm{s}$.

Changes in yield point elongation (Y.P.E.) and yield-to-tensile strength ratio (Y.S./T.S.) of steel A which were air cooled from annealing temperatures are shown in Fig. 1. Y.P.E. and Y.S./T.S. decrease with an increase in annealing time in $(\alpha+\gamma)$ region; the same tendency was found by Ōhashi et al. ${ }^{8)}$ The minimum time needed for the elimination of Y.P.E. and for the decrease in Y.S./T.S. becomes shorter as the intercritical annealing temperature becomes higher.

The effect of annealing time at $775^{\circ} \mathrm{C}$ on the Y.P.E. and Y.S./T.S. of steels A D which were air-cooled from annealing temperature, is shown in Fig. 2. Steel B, containing no $\mathrm{Cr}$, has a large Y.P.E. and Y.S./T.S. for a short annealing time, and has a little Y.P.E. even when it is annealed for $60 \mathrm{~min}$ at $775^{\circ} \mathrm{C}$. The increase in $\mathrm{Cr}$ content decreases Y.P.E. and Y.S./T.S.,



Fig. 1. Changes in yield point elongation (Y.P.E.) and yield-to-tensile strength ratio (yield ratio) of steel A air cooled from annealing temperature as a function of annealing temperature and time.



Fig. 2. Changes in Y.P.E. and Y.S./T.S. (yield ratio) as a function of holding time at $775^{\circ} \mathrm{C}$. (Each specimen was air-cooled from annealing temperature.)

and Steel D containing $0.9 \% \mathrm{Cr}$ has slight Y.P.E. and a low Y.S./T.S. even when it is annealed for $0.5 \mathrm{~min}$. The increase in Mn content decreases also Y.P.E. and Y.S./T.S. For example, steel G containing $2.3 \% \mathrm{Mn}$, annealed for $0.5 \mathrm{~min}$, has no Y.P.E. and the lowest yield ratio.

Figure 3 shows that the amount of second phase and internal friction values $\left(Q c^{-1}\right)$ vary with annealing time, cooling rate, and slightly with $\mathrm{Cr}$ content. The amount of second phase increases as the annealing time becomes longer. Carbon in ferrite in $(\alpha+\gamma)$ region decreases, that is to say, carbon in austenite in $(\alpha+\gamma)$ region increases, with the increase in holding time at $775^{\circ} \mathrm{C}$ as indicated from the internal friction values obtained for the water-quenched steels.

The comparison of Figs. 2 and 3 suggests that the changes in yield ratio and yield point elongation have close relations with the amount of second phase and solute carbon content. So, the assumption will be examined as follows.

The effects of second phase content and internal 
friction value on the yield ratio are shown in Fig. 4. The yield ratio of steels air cooled from annealing temperature reaches a minimum value at about $3 \%$ of second phase for steel A containing Cr, but does not reach a minimum value even at about $10 \%$ of second phase for steel B containing no Cr. Steel A has also much lower yield ratios than steel $B$ has at the same second phase content for both air-cooled and waterquenched conditions. The effect of $Q c^{-1}$ on the yield ratio is not clear from this figure.

The question remaining is how to explain the difference in the yield ratios obtained at the same second phase content for steel A and for steel B. The transformation temperature of austenite in the air cooling varies from steel $\mathrm{A}$ to steel $\mathrm{B}$ as shown in Fig. 5, and these results imply that the structure of the second phase is different from each other. So, the structure of the second phase was examined.

Typical optical micrographs of steels A and B are shown in Photo. 1. These optical micrographs and transmission electron micrographs revealed that the hard phases for water-quenched steels are composed of martensite, and that the type of hard phases for aircooled steel depends on the composition of the steel and on the holding time at $775^{\circ} \mathrm{C}$. In air cooled condition, the hard phases for steel A containing $\mathrm{Cr}$
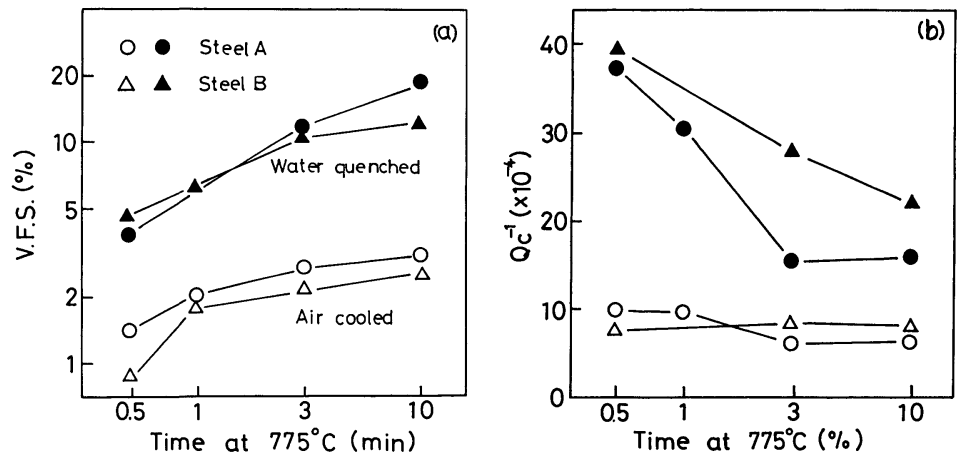

Fig. 3. Effect of holding time at $775^{\circ} \mathrm{C}$ on the volume fraction of second phase (V.F.S.) and internal friction value $\left(Q c^{-1}\right)$. are mainly composed of martensite and those for steel B containing no $\mathrm{Cr}$ are mainly composed of bainite. The martensite content increases with an increase in holding time for both steels. The reason why the martensite content depends on the chemical composition and holding time is that the stability of $\gamma$ phase is increased with the addition of $\mathrm{Cr}$ and increase in carbon content during holding at $775^{\circ} \mathrm{C}$ as indicated in Fig. 4.

The change in yield ratio as a function of martensite content and of low temperature transformation products (LTTP) is shown in Fig. 6. It can be concluded that yield ratio is primarily a function of martensite content and not of bainite content.

The effect of metallurgical variables on the yield point elongation will be examined as follows. The effect of second phase content on the Y.P.E. is shown in Fig. 7(a). The number in the parenthesis in Fig. 7 indicates the annealing time at $775^{\circ} \mathrm{C}$. The Y.P.E. of air-cooled steels reduces as the second phase content increases; it disappears at relatively small amount

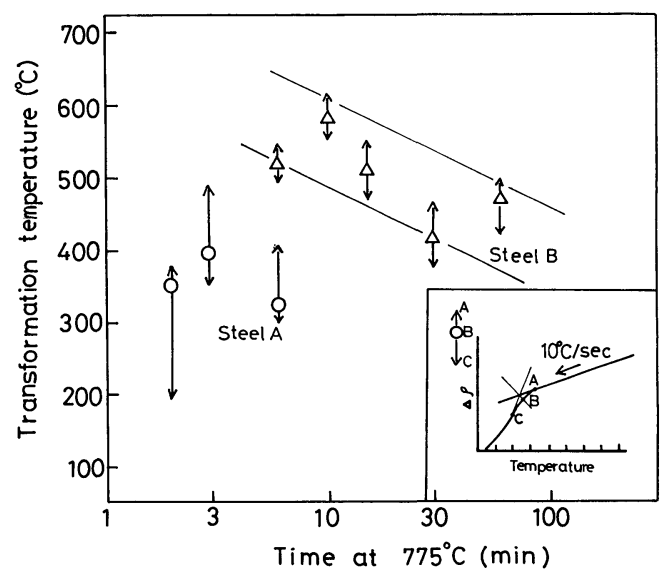

Fig. 5.

The change in transformation temperature of steels $\mathrm{A}$ and $\mathrm{B}$ as a function of holding time at $775^{\circ} \mathrm{C}$. (Cooling rate is about $10^{\circ} \mathrm{C} / \mathrm{s}$.)
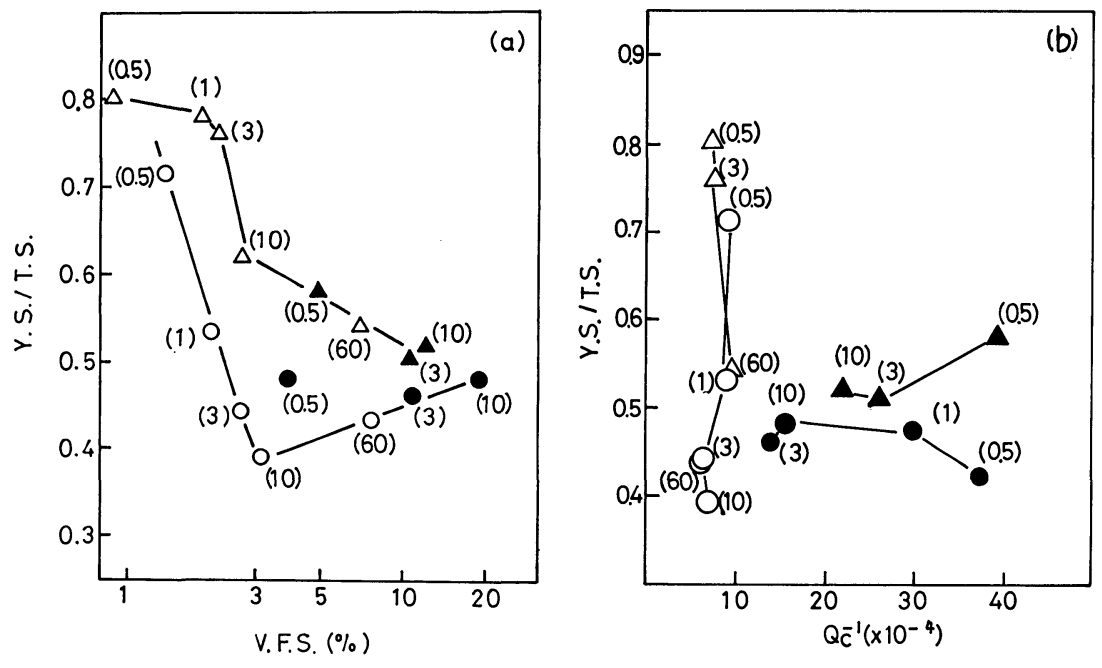

Fig. 4. Changes in yield ratio as a function of second phase content and $Q c^{-1}$. The number in the parentheses indicates the holding time at $775^{\circ} \mathrm{C}$.



Fig. 6.

Relationships between yield ratio and the amount of martensite and of low temperature transformation products (LTTP). Marks are the same as in Fig. 4. 
$(2 \sim 3 \%)$ of the second phase for steels containing $\mathrm{Cr}$, but the disappearance may not take place under the volume fraction of less than $10 \%$ for the steel without Cr. It may be concluded from Fig. 7(b) that $Q c^{-1}$ has little effect on Y.P.E., because specimens waterquenched (for steel B) have no Y.P.E. even though solute carbon content varies from one specimen to another.

Aichbhaumik and Goodhart ${ }^{5}$ ) found that tensile strength and elimination of Y.P.E. are primarily functions of volume percent of the hard phase. They also found that a smallest amount of the hard phase needed for the complete elimination of discontinuous yielding varies a little from one alloy to another and depends a little on the annealing temperature. The results shown in Fig. 7 are the same as that found by Aichbhaumik and Goodhard.5) They attributed the difference in tensile strength to the grain size, and the size, distribution pattern and the number of hard phase particles. However, they did not mention the reason for the difference in the minimum amount of hard phase needed for the complete elimination of Y.P.E.

Figure 8 shows the variation of Y.P.E. as a function of the amount of martensite and of low temperature transformation products (LTTP) for steels A and B. It can be concluded from Figs. 7(a) and 8 that martensite has much larger effect on the decrease in Y.P.E. than bainite has, and that the difference in the minimum amount of the hard phase needed for the complete elimination of Y.P.E. can primarily be explained by the difference in the martensite content between steel $\mathrm{A}$ and steel $\mathrm{B}$.

Figures 6 and 8 indicate that the difference in the amount of hard phases needed for the decrease in yield ratio and for complete elimination of yield point

Photo. 1.

Microstructural changes in steels $\mathrm{A}$ and $\mathrm{B}$ as a function of holding time at $775^{\circ} \mathrm{C}$ and cooling rate.

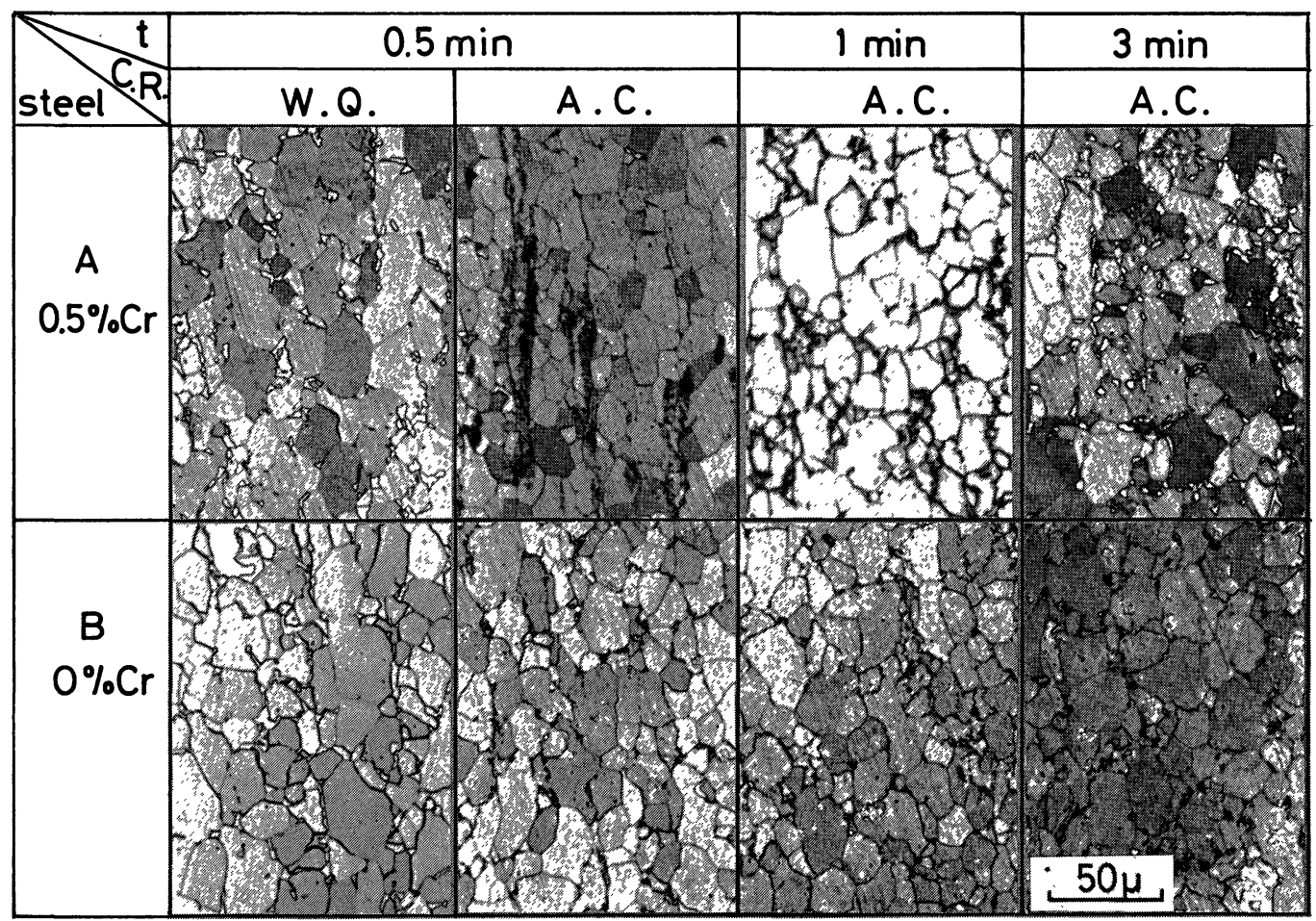
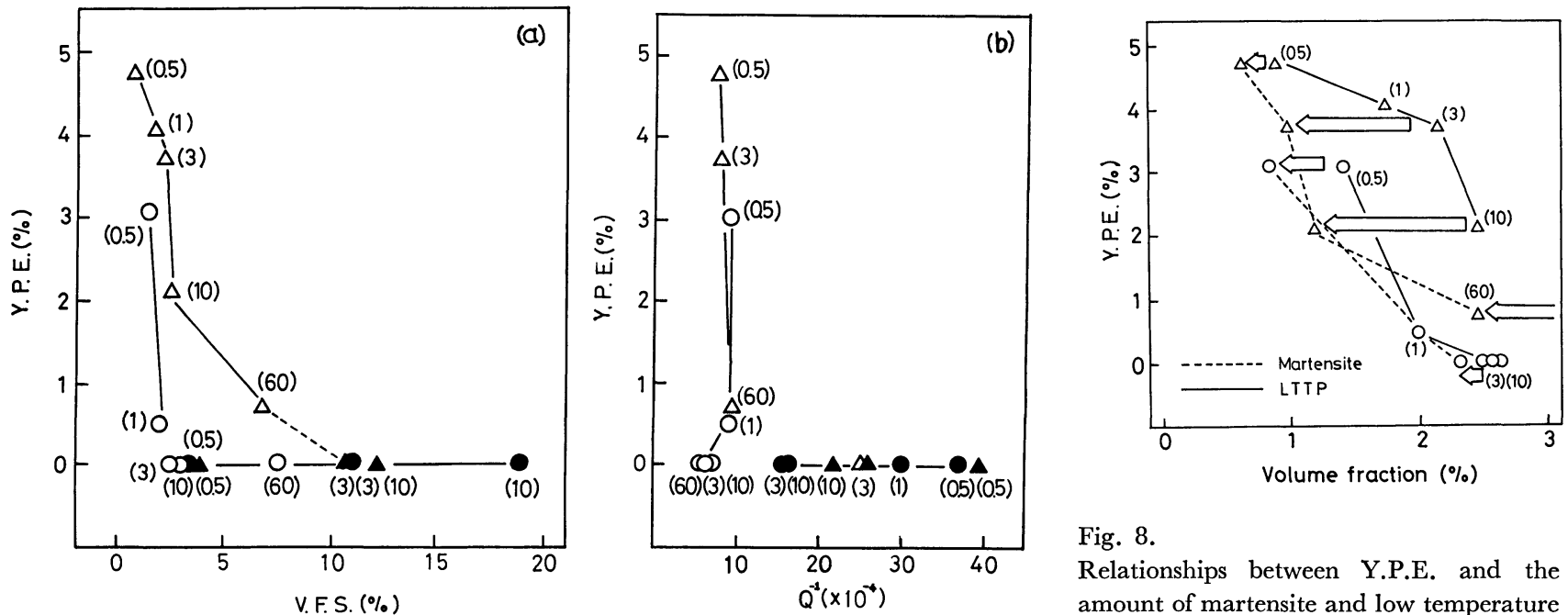

Fig. 8.

Relationships between Y.P.E. and the amount of martensite and low temperature transformation products (LTTP).

Fig. 7. Effect of second phase content and $Q c^{-1}$ on yield point elongation (Y.P.E.). 
elongation must be primarily attributable to the type of hard phases. Bainite has a much smaller effect in diminishing yield ratio and in eliminating yield point elongation than martensite has. High yield ratio and yield point elongation of ferrite-bainite steel can be lowered by introducing small amount of martensite.

Figures 4 and 7 indicate that solute carbon in ferrite has a minor effect on yield ratio and yield point elongation.

Even though a complete understanding of the mechanism of these phenomena has not been obtained yet, ${ }^{9,10)}$ the results presented here provide evidence that ferritic-martensitic structure is the best for obtaining typical " dual phase" steel having a low yieldto-tensile strength ratio and no yield point elongation.

The effect of microstructure on the strength-uniform elongation relationships was not mentioned here, because there were many papers written on this subject, ${ }^{2,3,11)}$ but our results were the same as those found in the papers; ferritic-martensitic $(F+M)$ structure has a favorable effect and bainite structure has a slight detrimental effect on strength-uniform elongation relationships.

\section{Stretch-flangeability}

The steels $A \sim D$ were also used to examine the effect of microstructure on stretch-flangeability. Hole expanding limit $\lambda$ decreases rapidly with increasing tensile strength as shown in Fig. 9. Figure 9 also implies that hole expanding limit depends on cooling rate and $\mathrm{Cr}$ content. The change in $\lambda$ with cooling rate and $\mathrm{Cr}$ content is attributable to the change in type and content of second phase. To test this hypothesis, the relationship between $\lambda$ and volume fraction of second phase and martensite was examined.

Figure 10 shows that hole expanding limit $\lambda$ decreases rapidly with increasing LTTP content. $\lambda$ is also dependent on the nature of LTTP. Ferritebainite-martensite steel B (whose bainite content is larger than martensite content) has superior $\lambda$ than ferrite-martensite steel B water quenched when compared at a same volume fraction, and has superior $\lambda$ than air-cooled ferrite-martensite-bainite steel A (whose martensite content is larger than bainite content) when compared at a same content of martensite. Ferrite-bainite steels which were obtained through isothermal transformation has a good stretch-flangeability as ferrite-bainite-martensite steel. It is confirmed that ferrite-bainite steel has better stretchflangeability than ferrite-martensite steel, and that the $\lambda$ of ferrite-martensite steel is improved through introducing bainite structure into $\mathrm{F}+\mathrm{M}$ steel.

It is well known that true strain at ductile fracture is a strong function of the volume fraction of the particles, and that in some cases, the reduction of area is dependent on particle shape, such as, in a eutectoid steel. ${ }^{12)}$

To confirm the effect of the type of hard phases on the stretch-flangeability, several kinds of cold-rolled steel were prepared and heat-treated to give the different types of microstructures.

Hole expanding limit is also dependent on tensile



A.C.: air cooled from $775^{\circ} \mathrm{C}$

I.T.: intercritically annealed and then isothermally treated at $400^{\circ} \mathrm{C}$

W.Q.: water quenched from $775^{\circ} \mathrm{C}$

Fig. 9. Relationship between hole expanding limit $(\lambda)$ and tensile strength (T.S.).

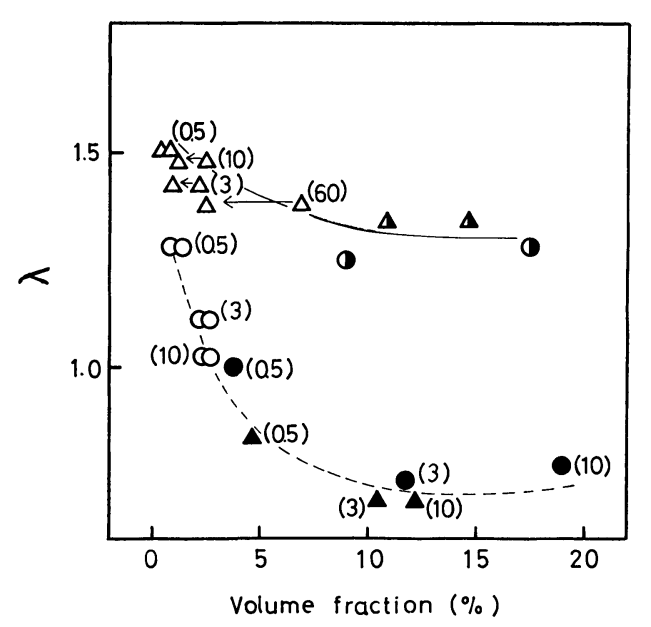

Fig. 10. Relationships between hole expanding limit and the amount of martensite and of low temperature transformation products (LTTP).

strength as shown in Fig. 11. Bainitic steels have a high strength-expanding limit relationship compared with ferritic-martensitic steels, as expected.

Exceptionally high $\lambda$ was obtained for ferritic-martensitic steels having a high $r$ value. So, the effect of $r$ value on $\lambda$ was examined. Figure 12 indicates that the hole expanding limit is extremely dependent on $r$ value, both in ferritic-pearlitic and in ferriticmartensitic steels. This phenomenon is well known in ferritic-pearlitic steel. ${ }^{13)}$ The strain distribution at the hole is like that of deep drawn parts and then, the hole expanding limit of a cold rolled sheet is substantially affected by its $r$ value, especially minimum $r$ value. Also in the case of ferritic-martensitic steel it is confirmed that excellent stretch-flangeability can be expected when $r$ value is high.

It can be concluded that bainite has a favorable effect on ductile fracture. This effect is consistent with traditional views of void nucleation, void growth, and void coalescence. In the case of ferritic-bainitic 


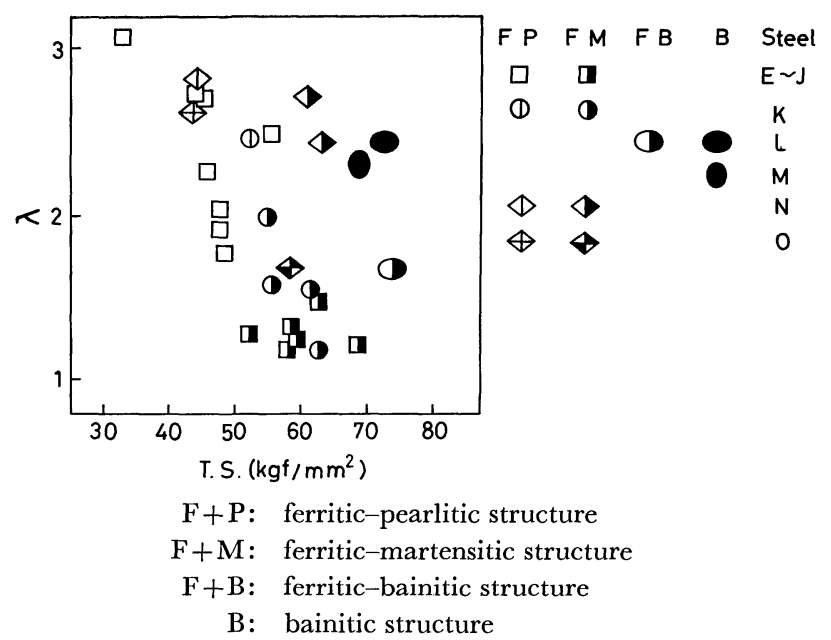

Fig. 11. Relationship between hole expanding limit $\lambda$ and tensile strength. (Machined hole was used.)



Fig. 12. Relationship between hole expanding limit $\lambda$ and $\bar{r}$ value. (Machined hole was used.)

Marks are the same as in Fig. 11.

steels, the strain needed for void nucleation and growth is larger than in the case of ferritic-martensitic steels. This may be due to the difference in the hardness of bainite and martensite. Due to the difference in stress concentration around hard phases, void formation is very sensitive not only to amount and hardness of particle (hard phase), but also to particle size and particle distribution. So, the relationships between $\lambda$, and particle size, and particle distance were examined. The results show that $\lambda$ becomes a little higher when particle size is small and particle distance is long. However, the effect of $r$ value is much larger than the effect of particles, so the results were not shown in this paper.

It is, also concluded that the $\lambda$ of ferrite-martensite steel can be improved through improving the $\bar{r}$ value.

\section{Fracture Toughness of Deep-drawn Cups}

No delayed cracking or splitting occurred for all drawn cups examined. So the fracture toughness was evaluated at various low temperatures by expanding the notched short rings cut from drawn cups.

The transition temperature of deep drawn cups becomes higher as the strength increases as shown in Fig. 13. These results show that bainitic and ferriticbainitic steels have slightly lower $v T_{r s}$ than ferritic-



Fig. 13. Relationship between transition temperature of deep drawn cups and tensile strength of sheet steels.

Marks are the same in Fig. 11



Fig. 14. Effect of $\bar{r}$ value of sheet steels on the transition temperature of deep drawn cup.

Marks are the same as in Fig. 11.

martensitic steels containing no Nb.

Figure 14 shows that $\mathrm{v}$ Trs of ferritic-pearlitic steels becomes lower as their $r$ value becomes higher, as was confirmed by Kokubo et al., ${ }^{14)}$ but that ferritic-martensitic phosphorous containing steel has especially high v Trs, even though it has a high $r$ value.

Fractographic features are examined to identify the fracture mode or mixture of modes occurring under brittle fracture test conditions. Examples of the typical fractographic features are shown in Photo. 2. These scanning electron microscope (SEM) fractographs are a little difficult to interpret in terms of ductile rupture, cleavage fracture, or brittle intergranular fracture mechanisms (or mixture thereof) without additional information relating the observed features to the microstructure. Typical fracture surfaces were nickel plated to provide edge retention during metallographic preparation. Careful examination of the microstructure and fractograph indicated that there was a tendency to cleavage fracture. But a tendency to mixture of cleavage and brittle intergranular fracture was observed for air-cooled $\mathrm{F}+\mathrm{M}$ steel, and a tendency to brittle intergranular fracture for $\mathrm{F}+\mathrm{M}$ steel containing phosphorous.

Figure 15 shows that transition temperature correlates with the unit crack path; the same tendency and additional findings were reported by Kunitake et $\left.a l .{ }^{15}\right)$ 



Photo. 2.

Fractographic features of deep drawn cups of various steels fractured at a lower temperature.



Fig. 15. Relationship between transition temperature of deep drawn cup and unit crack path.

Marks are the same as in Fig. 11.

In general, transition temperature is influenced by grain size and second phase. So, the relationship was examined especially on ferrite-martensite steel in order to improve the fracture toughness. The results showed that $\mathrm{v} T \mathrm{rs}$ of ferritic-martensitic steels is also influenced by grain size and the presence of second phase. The empirical relationship can be best expressed in terms of $\mathrm{v}$ Trs and V.F.S./G.S. as shown in Fig. 16.

Complete interpretation of this relationship has not been made yet. It is suggested that a small amount, small size and short distance of hard phases and fine grain size are preferred to obtain high toughness of ferrite-martensite steel (as far as the results obtained here are concerned).

In summary, bainite has a favorable effect on fracture toughness after cup deep drawing. On the contrary, martensite has a detrimental effect on fracture toughness of deep drawn cups, but the toughness of ferritic-martensitic steel is improved by controlling grain size and martensite particle distribution.

\section{Mechanical Properties}

In the previous section, it was confirmed that the ferrite-bainite-martensite steel has low yield ratio, no

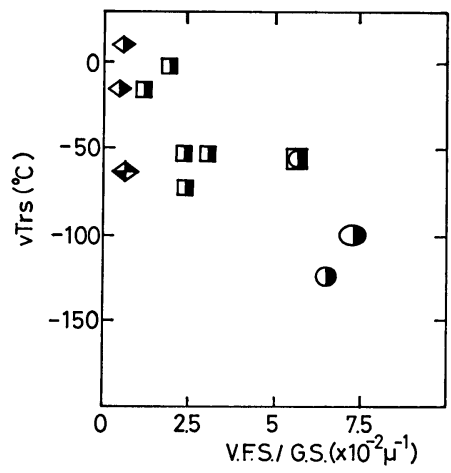

Fig. 16. Relationship between transition temperature $o$ deep drawn cup and V.F.S./G.S. where G.S. is grain size.

Marks are the same as in Fig. 11.

yield point elongation and good relationships between strength and hole expanding limit and fracture toughness after deep drawing. So, the effect of microstructure on the mechanical properties, especially elongation of multi-phase steels were briefly examined.

Some of the results are shown in Table 2. Waterquenched $\mathrm{F}+\mathrm{M}$ steels (A-1, A-2, B-1) have low yield ratio and no Y.P.E., but their combination of tensile strength and elongation (T.S. $\times$ El.) and $\lambda$ are inferior to other steels. Isothermally transformed $\mathrm{F}+\mathrm{B}$ steels (A-5, B-3) have high $\lambda$, but inferior values in other properties. The lowest yield ratio and best combination of tensile strength and elongation is obtained for air-cooled $F+M$ steel (A-3). However, $\lambda$ of the sample is inferior to $\mathrm{F}+\mathrm{B}$ steels (A-5, B-3). The comparison of the properties of sample A-1 and of A-3 indicates that solute carbon may have a detrimental effect on elongation.

Air-cooled ferrite-bainite-martensite steel (A-4) has nearly the best combination of tensile strength and elongation and high $\lambda$. Sample B-2 has also a good combination of mechanical properties, except for a 
Table 2. Mechanical properties.

\begin{tabular}{|c|c|c|c|c|c|c|c|c|}
\hline \multirow{2}{*}{ Steel } & \multirow{2}{*}{$\begin{array}{c}\text { Microstructure } \\
(\%)\end{array}$} & \multicolumn{6}{|c|}{ Mechanical properties } & \multirow[b]{2}{*}{$\lambda$} \\
\hline & & $\begin{array}{c}\text { Y.S. } \\
\left(\mathrm{kgf} / \mathrm{cm}^{2}\right)\end{array}$ & $\begin{array}{c}\text { T.S. } \\
\left(\mathrm{kgf} / \mathrm{mm}^{2}\right)\end{array}$ & $\begin{array}{l}\text { El. } \\
(\%)\end{array}$ & Y.S./T.S. & T.S. $\times$ El. & $\begin{array}{l}\text { Y.P.E. } \\
(\%)\end{array}$ & \\
\hline A-1 & $\mathrm{F}+19.0 \mathrm{M}$ & 30.82 & 64.68 & 19.1 & 0.48 & 1233 & 0 & 0.77 \\
\hline 2 & $\mathrm{~F}+11.8 \mathrm{M}$ & 28.39 & 62.12 & 21.8 & 0.46 & 1354 & 0 & 0.74 \\
\hline 3 & $\mathrm{~F}+2.5 \mathrm{M}+0.2 \mathrm{~B}$ & 18.63 & 47.43 & 34.8 & 0.39 & 1652 & 0 & 1.02 \\
\hline 4 & $\mathrm{~F}+2.7 \mathrm{M}+18.5 \mathrm{~B}$ & 27.97 & 53.79 & 28.8 & 0.52 & 1549 & 0 & 1.26 \\
\hline 5 & $\mathrm{~F}+17.6 \mathrm{~B}$ & 33.46 & 49.25 & 26.9 & 0.68 & 1327 & 0.93 & 1.29 \\
\hline B-1 & $\mathrm{F}+12.2 \mathrm{M}$ & 33.89 & 64.72 & 19.6 & 0.52 & 1269 & 0 & 0.69 \\
\hline 2 & $\mathrm{~F}+2.4 \mathrm{M}+6.4 \mathrm{~B}$ & 23.35 & 43.06 & 35.9 & 0.54 & 1546 & 0.58 & 1.38 \\
\hline 3 & $\mathrm{~F}+14.8 \mathrm{~B}$ & 36.93 & 44.32 & 32.4 & 0.83 & 1436 & 4.77 & 1.34 \\
\hline
\end{tabular}

slight yield point elongation. It can be concluded that the improvement of mechanical properties of ferrite-bainite steel is obtained through introducing a small amount of martensite $(2 \sim 4 \%)$. The authors found, also that $\mathrm{F}+\mathrm{B}(+\mathrm{M})$ steels have a higher $\bar{r}$ value than $\mathrm{F}+\mathrm{M}$ steels. ${ }^{16)}$ So, it is suggested that triphase $(\mathrm{F}+\mathrm{B}+\mathrm{M})$ steel can be one of the most favorable steels used for press forming or for automotive industries.

The effect of retained austenite is not mentioned in this study, because the amount of $\gamma$ is very small and the effect is thought to be smaller as compared with martensite, bainite and carbon in ferrite. ${ }^{17)}$

The quantitative study on the effect of volume fraction of bainite, martensite and retained austenite on the mechanical properties of multi-phase steel is being carried out.

\section{Conclusion}

The effect of the nature of the low temperature transformation products on the mechanical properties, stretch-flangeability, and fracture toughness after cup deep drawing of multi-phase sheet steels were studied.

It was confirmed that martensite is the most preferred hard phase to diminish yield ratio to eliminate yield point elongation, and to achieve the best combination of strength-uniform elongation. Formation of bainite should certainly be prevented.

However, bainite has a favorable effect on stretch flangeability and fracture toughness after a cup deep drawing as compared with martensite. The yield ratio and yield point elongation of ferritic-bainitic steels are largely improved by introducing a small amount of martensite. It is also suggested that the ferritic-bainitic-martensitic (triphase) steel has nearly the best combination of mechanical properties; low yield ratio, no yield point elongation, good strengthelongation balance, stretch-flangeability and fracturetoughness after deep drawing.

The stretch-flangeability of ferritic-martensitic steel is improved with an increase in $r$ value and the fracture toughness after deep drawing of $\mathrm{F}+\mathrm{M}$ steel is improved through decreasing ferrite grain size.

In conclusion, ferritic-bainitic-martensitic (triphase) steel may be preferred to dual phase steel in some complex pressing; for example deep drawing and hole expanding deformation.

\section{REFERENCES}

1) T. Matsuoka and K. Yamamori: Met. Trans., 6A (1975), 1613.

2) Symposium on Structure and Properties of Dual-phase Steels, ed. by R. A. Kot and J. W. Morris, TMS-AIME, (1979).

3) Seminar on Dual Phase and Cold Pressing Vanadium Steels in the Automobile Industry, VANITEC, (1978).

4) R. G. Davies: Met. Trans., 9A (1978), 41.

5) D. Aichbhaumik and R. R. Goodhart; SAE Paper No. 790010, (1979).

6) T. Oki, Z. Shibata and M. Sudo: SAE Paper No. 8100030, (1981).

7) F. LePera: J. Metals, (1980), March, 38.

8) N. Ōhashi, I. Takahashi and K. Hashiguchi: J. Japan Soc. Tech. Plas., 17 (1976), 883.

9) S. Hayami and T. Furukawa: Micro Alloying 75, (1975), 311.

10) K. Kunishige, M. Takahashi, S. Sugisawa and Y. Masui: Tetsu-to-Hagané, 65 (1979), 1916.

11) J. M. Rigsbee, J. K. Abraham, A. T. Davenport, J. E. Franklin and J. W. Pickens: Symp. on Structure and Properties of Dual-phase Steels, TMS-AIME, (1979), 304.

12) H. C. Rogers and L. F. Coffin, Jr.: Final Report, Contract Now-66-0546-d, June 1967 (Naval Air Systems Command).

13) Y. Itō, K. Hashiguchi and N. Ōhashi: Proceedings of ICSTIS, suppl. Trans. ISIJ, 11 (1971), 958.

14) M. Sudo, T. Oki, Z. Shibata and I. Kokubo: Tetsu-toHagané, 59 (1973), S490.

15) T. Kunitake, F. Terasaki, Y. Ohmori and H. Ohtani: Toward Improved Ductility and Toughness, (1971), 83.

16) M. Sudo and Z. Shibata: Tetsu-to-Hagané, 67 (1981), S530.

17) G. T. Eldis: Symp. on Structure and Properties of Dualphase Steels, TMS-AIME, (1979), 202. 